\title{
Quality Relationships between Superiors and Subordinates as Well as Fellow Colleagues at the Sweetener and Fiber Research Center in 2010-2019
}

\author{
Isni Tri Lestari ${ }^{1}$, Maulina Pia Wulandari ${ }^{2}$, Zulkarnain Nasution ${ }^{3}$ \\ 1,2,3 Department of Communication, Faculty of Social and Political Sciences, \\ University of Brawijaya, Malang Indonesia \\ Email: isni3lestari@gmail.com
}

\begin{abstract}
Recurring organizational communication problems, lack of communication between superiors and subordinates, and also conflict at the employee level make the basis for researchers to conduct research and try to provide recommendations to improve conditions that occur in the Balittas organization. This study will focus on quality of relationships between superiors and subordinates as well as colleagues in organization. This study aims to describe and analyze the quality of the relationship between superiors and subordinates. This research was conducted using the Action Research method with the aim of being in Balittas from 2010 to 2019. Departing from the constructivism paradigm, this study carried out data collection by structured interviews and analyzed using the action research cycle from Coghland and Brannick. The quality of the relationship between superiors and subordinates, between colleagues for each period of each leader based on the LMX theory is dominated by the quality of the out group. This is because the relationship is only a contractual one. Subsequent research can develop the application of LMX theory in other government work units and create efforts to build quality in group relationships within Balittas. Based on LMX theory (low relationship quality) because the exchange of behavior of organizational members is limited to contractual ties and the low level of support and trust in each other.
\end{abstract}

Keywords: Relationship quality, LMX Theory.

\section{A. INTRODUCTION}

In activities to achieve goals, an organization is led by a leader. Pace and Faules (2013) define a leader as a person whose job is to help others achieve desired results. In the process, leadership is manifested through language and actions that give rise to a work style from the leader. The language patterns and actions of a leader in the organization describe a fairly consistent pattern which then gives rise to a leadership style. Current research supports the theory that the quality of the reciprocal relationship between a leader and his subordinates is determined to some extent by the leader's communication style, more specifically the way of verbal expression (Pacleb, 2016).

According to research conducted by Wulandari (2011), states that the quality of relationships within organizations is significantly influenced by the communication climate. The dimensions of organizational communication, namely openness, management-employee relations and satisfaction with the amount of information received, are summarized as factors that cause industrial conflict in an organization in Indonesia. The results show that employees feel dissatisfied with the amount of information they receive at that time, the communication climate in the organization 
is less open and the relationship between senior management and employees has problems. Another thing that is revealed in this study is that the quality of relationships within the organization, both superiors and subordinates or with fellow colleagues, needs to be analyzed in depth to find problems and then be able to determine the solution. Therefore, various studies are needed that can support knowledge about leadership and the quality of communication relationships within organizations. In line with the above research findings, experts in the field of organizational communication have identified the need for research on improving leadership communication and coworker communication (Heide \& Simonsson, 2011; Ruck \& Welch, 2012).

The Research Institute for Sweetener and Fiber Crops (One of the goverment research organization in Malang) is the Technical Implementation Unit (UPT) of the Ministry of Agriculture, under the coordination of the Center for Plantation Research and Development (Echelon II) and the Agricultural Research and Development Agency (Echelon I). One of the goverment research organization in Malang has the main task of carrying out research and development of sweetener crops (sugar cane, stevia, and sugar beet), fiber (fruit fiber, and stem and leaf fiber), tobacco and industrial oil (One of the goverment research organization in Malang, Performance Accountability Report of the Institute for Sweetener and Fiber Crops Research, 2017).

In carrying out their duties and functions, organizational members within the scope of the One of the goverment research organization in Malang communicate both from superiors to subordinates, subordinates to superiors, as well as parallel communication between subordinates or members with equal positions. These activities are inseparable from the process of the One of the goverment research organization in Malang organization in achieving its goals, but in the process, the IFCRI still experiences problems in the organizational communication process. According to the report documented in the 2017 Internal Audit Unit Customer Satisfaction Report, there is dissatisfaction in the communication process that occurs within the One of the goverment research organization in Malang scope. Some of the problems found were, among others, (1) lack of leadership guidance for employees; (2) lack of coordination from superiors to subordinates, (3) lack of coordination and consultation between top management and staff; (4) direction from superiors to all areas of customer complaints and follow-up improvements are considered slow (One of the goverment research organization in Malang, Internal Customer Satisfaction Report, 2017). Starting from the findings in the internal report, the researchers tried to trace and re-examine these findings by conducting interviews with officials at one of the goverment research organization in Malang. From the data collected by researchers in the preliminary research, it was known that this organization not really have a good quality of relationship 
Based on the findings of the problem phenomena that occur within the One of the goverment research organization in Malang organization and previous research studies discussed above, the researcher considers it necessary to carry out research to explore problems and find solutions to these problems. Recurring organizational communication problems, lack of communication between superiors and subordinates, and also conflict at the employee level make the basis for researchers to conduct research and try to provide recommendations to improve conditions that occur in the organization. This study will focus on discussing the quality of relationships between superiors and subordinates as well as colleagues.

\section{B. LITERATURE REVIEW}

Classical organization theory put forward by Max Weber (cited in Littlejohn \& Foss, 2008), which explains that organization is a rational system with regulatory power. Classical organization is very bound by the rules that apply in it, how goals have been set and the rules for achieving them must be followed, but it is less flexible and inflexible. Although Weber's views are rigid, they are widely followed because of his ability to better explain power and organize organizations.

The definition of leadership communication style is explained more simply by Johnson and Hackman (2018), namely the behavior of the leader in interacting with his subordinates who is attached to the leader. The communication style reflects the personality characteristics of leaders who are constant in doing their work and in interacting in their daily activities (Cheung \& To, 2015).

Judging from the results of previous research conducted by Sias (2005) which discusses the amount and quality of information received by employees related to work, it is related to the quality of their relationships with colleagues and superiors. The results show that the quality of the superior-subordinate relationship is positively related to the amount and quality of information received by employees from the leader or direct superior. That is, the relationship between superiors and subordinates can work well if the leader is open in providing information to his subordinates.

Organizational communication researchers in studying superior-subordinate communication are heavily influenced by the Leader Member Exchange (LMX) theory (Graen \& Scandura, 1987; Berger, Roloff, \& Roskos-Ewoldsen, 2011). In LMX theory, supervisors form various types of relationships with their various employees and these relationships vary with respect to quality.

According to LMX theory, there are two types of relationships formed between leaders and subordinates, namely in-group relationships and out-group relationships (Berger, Roloff, \& Roskos-Ewoldsen, 2010). A higher quality superior-subordinate relationship known as an in-group relationship is characterized by a higher level of mutual trust, respect, and obligation among the relationship partners. In such relationships, leaders and members learn that they can rely on each other for mutual support. This condition can produce a higher quality relationship and create a 
superior-subordinate relationship as a "partnership", whose members are willing to focus on the greater common interest "(Graen \& Uhl-Bien, 1995).

Out-group relationship is the opposite of in-group, which is the low quality of the relationship between superiors and subordinates (Berger, Roloff, \& RoskosEwoldsen, 2010). This low-quality relationship (low LMX) is characterized by the use of power status in the relationship between members, the exchange of behavior between members of the organization is limited to contractual ties, relationships between members are bound by their respective roles, low levels of support and trust, and rewards are limited to motives economics (Fairhurst, 2001). The impact of this out-group relationship is a lower level of subordinate satisfaction, a high rate of subordinate turnover, and a lower desire for subordinates to carry out their duties (Graen, Liden \& Hoel, 1982).

Kram \& Isabella (1985) divided peer relationships into three categories, namely (1) Information peer relationships, namely co-worker relationships characterized by low levels of self-disclosure and trust. Communication in this relationship focuses on limited, work-related content and reflects low levels of intimacy; (2) Collegial peer relationship, namely the relationship between colleagues characterized by a moderate level of trust, self-disclosure, emotional support, and friendship. Communication among peers reflects a broader range of content, including work-related and personal topics, and moderate levels of intimacy; (3) Special peer, namely the relationship between colleagues which is characterized by a high level of emotional support, communicating openly and providing feedback about careers, beliefs, individual personalities, and friendships. The relationship between colleagues in this category shows an almost unlimited breadth of conversational content and has a high level of intimacy.

\section{METHOD}

In this study using a constructivism paradigm. According to Denzin and Lincoln (2017), the constructivist paradigm is oriented towards understanding built from social reality. The method used in this research is action research or action research. Lewin (1947) described action research as a research process that runs in a spiral. The process consists of three steps, namely (1) planning, which involves indepth observation; (2) taking action; (3) evaluation.

The research location chosen was the Indonesian Sweetener and Fiber Crops Research Institute, which is an organization where researchers work as PR practitioners. One of the goverment research organization in Malang is located at Jalan Raya Karangploso KM. 4, Malang Regency, East Java Province. In this study, the data collection process refers to the action research stage. There are four stages, namely determining the diagnosis of leadership communication style problems, the quality of relationships between members of the organization. Second, planning an action strategy on how to solve the problem. Third, implement an action strategy. Finally, the evaluation of how leadership communication styles have implications for the quality of the relationship between organizational members. 
Interviews in action research tend to be open and unstructured, with a focus on what the interviewee is saying (Coghland \& Brannick, 2005). In line with the above opinion, Bryman (2008) explains that in-depth interviews can be in the form of unstructured or semi-structured interviews. An unstructured interview is a type of interview that only uses a list of topics or problems, which is often called an interview guide, and usually uses an informal questioning style.

Techniques to determine participants as data sources (informants) in this study using purposive techniques. According to Bryman (2008), purposive sampling technique is a strategic determination of the research sample, so that the sample is relevant to the research question posed. The criteria for informants in accordance with this research must have competence and knowledge about the leadership style of communication at One of the goverment research organization in Malang during 2010 to 2019, knowing how the quality of relationships between members of the organization, both superiors and subordinates and fellow colleagues. In this action research, researchers used the stages described by Coghland \& Brannick (2005) on the grounds that they provided the stages of action research analysis carried out for research carried out in the practitioner's own organization. This stage is a research cycle consisting of a pre-step containing context/objectives, and a main step containing four basic steps (diagnosing, planning action, taking action, evaluating action).

\section{RESULTS AND DISCUSSION}

According to LMX theory, there are two types of relationships formed between leaders and subordinates, namely in-group relationships and out-group relationships (Berger, Roloff, \& Roskos-Ewoldsen, 2010). A higher quality superior-subordinate relationship known as an in-group relationship is characterized by a higher level of mutual trust, respect, and obligation among the relationship partners. In such relationships, leaders and members learn that they can rely on each other for mutual support.

The quality of the relationship between superiors and subordinates during the term of 2016-2018 tenure led to in-group relationships. This is indicated by the informant's statement that there is mutual trust and respect between superiors and subordinates. In addition, leaders and subordinates carry out their obligations, duties and commitments in their work. Providing mutual support between superiors and subordinates also occurred during the leadership of the head of the hall.

Unlike the two leadership periods above, since 2010-2019 One of the goverment research organization in Malang is still dominated by the quality of outgroup relationships. This is quite worrying because according to the opinion of Graen, Liden, \& Hoel (1982) the impact of this out-group relationship is a lower level of subordinate satisfaction, a high rate of subordinate turnover, and a lower desire for subordinates to carry out their duties.

The outgroup relationship was seen during the leadership term 2010-2011, between in-group and out-group relationships. Outgroup relationships are characterized by statements from informants that in carrying out their obligations, 
duties and commitments are not carried out by subordinates. Subordinates also do not provide support to superiors. Outgroup relationships also appear during term 2012-2015 leadership. This is illustrated by the informant's statement that the leader is less able to commit to work, and the support between superiors and subordinates is low. Leaders also do not provide the information needed by employees. There is mutual trust between superiors and subordinates as well as mutual respect, but the implementation is only normative. Just trust and respect because of the rules and norms of manners that apply. The quality of the relationship between co-workers during the tenure of term 2012-2015 leads to informational peer relationships. This is marked by low mutual trust, self-disclosure and discussion of personal matters among fellow colleagues. Emotional support among co-workers is also low. There was no visible friendship formed. In addition, there is also a turnover of employees.

Out-group relationship is the opposite of in-group, which is the low quality of the relationship between superiors and subordinates (Berger, Roloff, \& RoskosEwoldsen, 2010). The quality of outgroup relationships was also found during term of 2018-2019. Although there is mutual respect and trust, the implementation is limited to a formality. Is carried out only in a contractual manner. In addition, this condition is strengthened by a lack of commitment in carrying out obligations and duties, superiors and subordinates do not provide support, information needed by employees is not provided by the leadership.

Outgroup relationships appear in the three terms of leadership and must be improved for the next term. This low-quality relationship (low LMX) is characterized by the use of power status in the relationship between members, the exchange of behavior between members of the organization is limited to contractual ties, relationships between members are bound by their respective roles, low levels of support and trust, and rewards are limited to motives economics (Fairhurst, 2001).

This study also describes the relationship between co-workers. Kram and Isabella (1985) divided peer relationships into three categories, namely (1) Information peer relationships, namely co-worker relationships characterized by low levels of selfdisclosure and trust. Communication in this relationship focuses on limited, workrelated content and reflects low levels of intimacy; (2) Collegial peer relationship, namely the relationship between colleagues characterized by a moderate level of trust, self-disclosure, emotional support, and friendship. Communication among peers reflects a broader range of content, including work-related and personal topics, and moderate levels of intimacy; (3) Special peer, namely the relationship between colleagues which is characterized by a high level of emotional support, communicating openly and giving each other feedback about careers, beliefs, individual personalities, and friendships. The relationship between colleagues in this category shows an almost unlimited breadth of conversational content and has a high level of intimacy.

The quality of relationships between colleagues during the tenure of the term 2018-2019 and leadership term 2016-2018 tenure have led to informational peer relationships. This is marked by low mutual trust, self-disclosure and discussion of 
personal matters among fellow colleagues. Openness among employees is only at a moderate level. Emotional support among co-workers is also low. The formation of friendship into certain groups, there are groups that are for and against the leadership of the head of the Balai.

Furthermore, during the time of term 2018-2018. In this case, the researcher could not find the type of quality of the relationship between superiors and subordinates as well as fellow colleagues who could not be identified properly by the informants. This is because term 2018-2018 is only three months and only one month is effectively leading at the hall.

According to Berger, Roloff \& Ewoldsen (2010), the assumption of LMX theory is that leaders build relationships of varying quality among subgroups of sub-groups, rather than linking them uniformly. There are two types of relationships formed between leaders and subordinates, namely in-group relationships and out-group relationships. The results of this study indicate that organization still has the quality of outgroup relationships, so that this can be an important note for the next hall leadership in order to create quality in-group relationships.

\section{E. CONCLUSION}

The results showed that the quality of the relationship between superiors and subordinates and co-workers in out group relationship. An interesting finding in this study is that it is known from the results of the Lakin performance report that there is no decrease in performance achievement even though there has been a change of leadership in a fairly short period of time. The quality of the relationship between superiors and subordinates in the 2010-2019 period still reflects the quality of out group relationships based on LMX theory (low relationship quality) because the exchange of behavior of organizational members is limited to contractual ties and the low level of support and trust in each other.

\section{REFERENCES}

1. Berger, C. R., Roloff, M. E., \& Roskos-Ewoldsen, D. R. (2011). Handbook Ilmu Komunikasi. Bandung: Nusa Media.

2. Berger, R., Roloff, M. E., \& Roskos-Ewoldsen, D. R. (2010). What is communication science?. In The Handbook of Communication Science (3-20). Thousand Oaks, CA: SAGE Publications, Inc. https://doi.org/10.4135/9781412982818.n1

3. Brannick, T., \& Coghlan, D. (2007). In defense of being "native": The case for insider academic research. Organizational research methods, 10(1), 59-74.

4. Bryman, A. (2008). Social Research Methods. Oxford: Oxford University Press.

5. Cheung, F. Y., \& To, W. M. (2015). Do task- and relation-oriented customers cocreate a better quality of service? An empirical study of customer-dominant logic. Management Decision, 53, 179-197. https://doi.org/ccj5

6. Chin, R. J. (2015). Examining teamwork and leadership in the felds of public administration, leadership, and management. Team Performance Management: An 
International Journal, 21(3/4), 199-216. doi: http://dx.doi.org/10.1108/TPM-07-20140037

7. Costello, P. J. (2003). Action Research. London: Continuum.

8. Creswell, J. W. (2009). Research Design: Qualitative, Quantitative, and Mixed Methods Approaches. Thousand Oaks, California: SAGE Publications, Inc.

9. De Vries, R., Bakker-Pieper, A., \& Oostenveld, W. (2010). Leadership= communication? The relations of leaders' communication styles with leadership styles, knowledge sharing and leadership outcomes. Journal of Business and Psychology, 25(3), 367-380. 10.1007/s10869-009-9140-2

10. Denzin, N. K., \& Lincoln, Y. S. (Eds.). (2011). The SAGE Handbook of Qualitative Research. Thousand Oaks, California: SAGE Publication, Inc.

11. Fairhurst, G. T. (2001). Dualisms in leadership research. In F.M. Jablin E L. L. Putnam. The New Handbook of Organizational Communication (379-439). Thousand Oaks, CA: SAGE Publications, Inc. https://doi.org/10.4135/9781412986243

12. Graen, G. B., \& Scandura, T. A. (1987). Toward a psychology of dyadic organizing. Research in Organizational Behavior, 4, 99-112. http://dx.doi.org/10.1111/j.14682958.1978.tb00600.x

13. Graen, G. B., \& Schiemann, W. A. (2013). Leadership-motivated excellence theory: An extension of LMX. Journal of Managerial Psychology, 28(5), 452-469. http://dx.doi.org/10.1108/JMP-11-2012-0351

14. Graen, G. B., \& Uhl-Bien, M. (1995). Relationship-based approach to leadership: Development of leader-member exchange (LMX) theory of leadership over 25 years: Applying a multi-level multi-domain perspective. The Leadership Quarterly, 6(2), 219-247. https://doi.org/10.1016/1048-9843(95)90036-5

15. Graen, G. B., Liden, R. C., \& Hoel, W. (1982). Role of leadership in the employee withdrawal process. Journal of applied psychology, 67(6), 868.

16. Heide, M. \& Simonsson, C. (2011). Putting co-workers in the limelight: new challenges for communication professionals. International Journal of Strategic Communication, 5(1), h. 55-68

17. Johnson, Craig E. \& Hackman, Michael Z., (2018). Leadership a Communication Perspective. Long Grove, Illinois: Waveland Press, Inc.

18. Kram, K. E., \& Isabella, L. A. (1985). Mentoring alternatives: The role of peer relationships in career development. Academy of management Journal, 28(1), 110-132.

19. Lewin, K., Lippitt, R., \& White, R. K. (1939). Patterns of aggressive behavior in experimentally created "social climates". Journal of Social Psychology, 10, 271-299.

20. Littlejohn, S. W., \& Foss, K. A. (2008). Theories of human communication. Belmont, CA: Thomson/Wadsworth.

21. Novac, C., \& Bratanov, C. I. (2014). The impact of the leadership style on the organizational climate in a public entity. Management Dynamics in the Knowledge Economy, 2(1), 155-179.

22. Pace, R. W., \& Faules, D. F. (2013). Komunikasi Organisasi Strategi Meningkatkan Kinerja Perusahaan. Bandung: Remaja Rosdakarya. 
23. Ruck, K. and Welch, M. (2012). Valuing internal communication: management and employee perspectives. Public Relations Review, 38(2), 294-302. doi: 10.1016/j.pubrev.2011.12.016

24. Wulandari, M. P. (2011). Evaluating Organisational Communication and Workplace Industrial Relations: An Indonesian Case Study. Doctoral dissertation, University of Newcastle Australia.

25. Yulk, G. (2009). Leadership in Organizations. Essex: Pearson Education Limited. 